\title{
Notes on Fanniidae (Diptera) of Finland, with a description of the female of Fannia stigi Rognes, 1982
}

\author{
Jere Kahanpää \& Antti Haarto
}

Kahanpää, J. \& Haarto, A. 2013: Notes on Fanniidae (Diptera) of Finland, with a description of the female of Fannia stigi Rognes, 1982. - Entomol. Fennica 24: 179-185.

This paper documents the presence of 20 species of Fanniidae in Finland. Fannia alpina Pont, 1970 and F. slovaca Gregor \& Rozkošný, 2005 are new to North Europe. Fannia barbata (Stein, 1892), F. lineata (Stein, 1892) and F. nigra Malloch, 1910 are removed from the Finnish checklist. The female of Fannia stigi Rognes, 1982 is described from a Finnish specimen caught together with a male. The total number of fanniid flies known from Finland is now 61.

J. Kahanpää, Finnish Museum of Natural History, Zoology, P.O. Box 17, FI00014 University of Helsinki, Finland; E-mail: jere.kahanpaa@helsinki.fi

A. Haarto, Zoological Museum, Section of Biodiversity and Environmental Science, University of Turku, FI-20014 Turku, Finland

Reveived 17 January 2013, accepted 5 March 3013

\section{Introduction}

The dipterous family Fanniidae is a smallish family of mostly black, rather unconspicuous flies. About 85 species are known from Europe (Pont 2012). The larvae are saprophagous and feed on a range of decaying organic tissues like rotting wood, old fungi, cadavers, faeces and bird or mammal nests. A few species are pests or known to cause myiasis in severely weakened hosts.

Fanniids have attracted relatively little attention in Finland. Lauri Tiensuu (1906-1980) studied them in the 1930s as a part of a larger project on muscoid flies. He returned to the family in the sixties and seventies, but did not publish any new papers during the latter period.

This is reflected by the slow increase in the number of species known from Finland: 37 species were listed in 1941 (Tiensuu 1941). Only two had been added by 1980 for a total of 39 species (Hackman 1980). The latest decade has seen a surge of interest in brachyceran flies in Finland, and many new species have been recorded in the country. Rozkošný et al. (1997) list 46 fanniids from Finland. Fannia atra (Stein, 1895) has recently been reported from Finland by Haarto (2009). The additional records presented in this paper raise the total number of Fanniidae known from Finland to 61.

\section{Material and methods}

Finnish biogeographical provinces are abbreviated using the standard Latinate forms. Complete province names in a map are presented in all volumes of Fauna Entomologica Scandinavica. Coordinates are given in Finnish National Coordinate System (yhtenäiskoordinaatisto, YKJ) (Heikinheimo \& Raatikainen 1971). The discussed material is deposited in the Finnish Museum of Natural History $(\mathrm{MZH})$ and the private collections of the authors, Kaj Winqvist, Jari Flinck, and Iiro Kakko. 


\section{New records of Fanniidae from Finland}

\section{Fannia aethiops Malloch, 1913}

New to Finland. A Holarctic species that is widespread in North America, but previously recorded only from Norway and Sweden in Europe (Pont 1986, 2012).

Material examined. FINLAND 1 $\widehat{\sigma}$ Ks: Kuusamo, Paahtojärvi (7347004:3614371), 20.VI.-3.VIII.2005, leg. J. Salmela, malaise trap, a small stream. 2 ते $K s$ : Taivalkoski, Pahkaoja (7281402:3560358), 30.V.-3.VII.2006, leg. J. Salmela, malaise trap, a wet north boreal forest with spruce and willows.

\section{Fannia alpina Pont, 1970}

New to North Europe. One of the most surprising finds was a male of this very rarely collected species from Finland. The locality is a highway verge cutting through small-scale farming land and it harbours a strong (if fluctuating) population of the greater knapweed (Centaurea scabiosa). Fannia alpina was described from the Austrian Alps (Pont 1970). It has also been found in Japan (Nishida 1974) and Nepal (Nishida 1994). The Finnish site is far from any mountains and repre- sents rather typical south boreal lowland landscape dominating the southern half of Finland.

Material examined. FINLAND 1 o Ta: Heinola, Lusi, Vanha-Sipilä (67983:34500), 26.VII.2009, leg. J. Kahanpää (id jka09-06049). Illustrated in Fig. 1.

\section{Fannia carbonella (Stein 1895)}

Previously listed from Finland by Pont (2012).

Material examined. FINLAND $1 \hat{\sigma} \mathrm{Ka}$ : Hamina, 18.VI.1963, leg. L. Tiensuu, id http:// id.luomus.fi/HT.793. RUSSIA $1 \curvearrowright$ Republic of Karelia, Sortavala, leg. L. Tiensuu, id http://id. luomus.fi/HT.772.

\section{Fannia fuscitibia Stein, 1920}

New to Finland.

Material examined. FINLAND 1 o $L i$ : Enontekiö, Kilpisjärvi, Annjalonji, 13.VII.2010, leg. Iiro Kakko.

\section{Fannia gotlandica Ringdahl, 1926}

New to Finland. A rare species hitherto known only from Sweden and the British Isles (Pont 2012).

Material examined. FINLAND $1 \bigcirc A b$ : Turku, Satava (67047:32310), 25.VIII.2002, leg. K. Winqvist, caught at light at night.

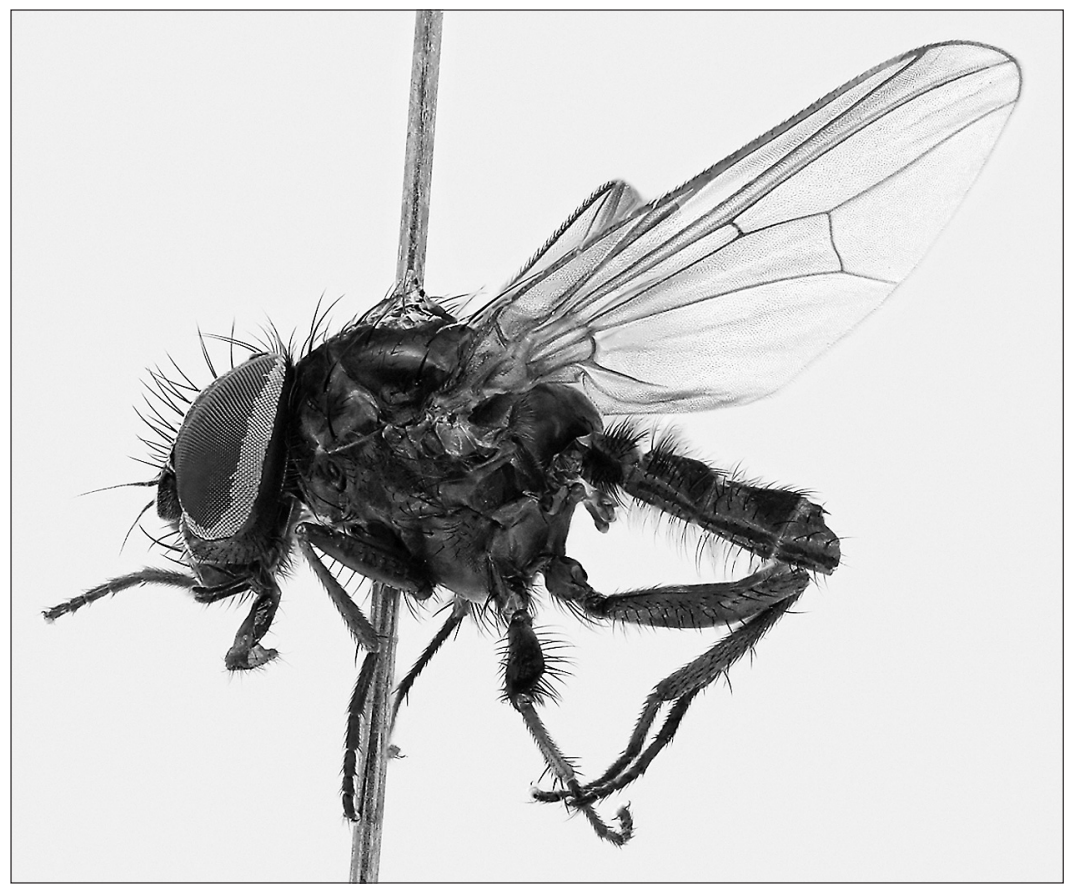

Fig. 1. Fannia alpina Pont, 1970, male. Tip of abdomen detached. 


\section{Fannia immutica Collin, 1939}

Listed from Finland by Pont (2012), but we have been unable to locate any correctly identified museum specimens.

Material examined. FINLAND 1 ते $O k$ : Puolanka, Kurikkavaara (71868:35379), 12.VII. 2002, leg. J. Kahanpää, id jka06-0340. 1 ๙ Al: Finström, Bergö Husö (6706:3103), 8.-9.IX. 2012, leg. Haarto, Jokinen \& Virta, id AHa12002184. 1ㅇ Sb: Kuopio, Puijo (6978: 3533), 31.VII.2012, leg. A. Haarto, id AHa12-002420. 2 ㅇ Sb: Kuopio, Kolmisoppi (6974: 3530), 1.VIII.2012, leg. A. Haarto, id AHa12-002341 \& -002342 .

\section{Fannia latipalpis (Stein, 1892)}

New to Finland.

Material examined. FINLAND $1 \circlearrowleft N$ : Helsinki, Vuosaari (6679:3397), 2.VIII.2002, leg. J. Kahanpää.

\section{Fannia leucosticta (Meigen, 1838)}

The species is first mentioned in Tiensuu (1946a) from Finland, although his collecting locality is now in the Russian territory. Pont (1986) and Rozkošný et al. (1997) record this species from Finland. Pont (2012) lists the occurrence as doubtful. There are four male specimens under this name in Finnish collections (all in MZH). Two males belonging to $F$. leucosticta were found in the MZH Diptera Fennica collection. A pair from Vieljärvi (Russia) identified as Azelia gibberoides by Tiensuu belong to Azelia triquetra (Wiedemann, 1817) (Muscidae).

Material examined. FINLAND 1 ते $A b$ : Bromarv, 20.-22.VII.1960, leg. S. Laurema, id http://id.luomus.fi/HT.779. RUSSIA 1 ๙ Leningrad Oblast, Vaaseni, 11.VI.1942, leg. L. Tiensuu, id http://id.luomus.fi/HT.781.

\section{Fannia metallipennis (Zetterstedt, 1838)}

Previously listed from Finland by Rozkošný et al. (1997) and Pont (2012).

Material examined. FINLAND $1 \hat{\mathrm{K}} \mathrm{Ka}$ : Hamina, Lankamalmi, larva found 24.III.1973 in leaf litter, leg. L. Tiensuu, adult mounted with puparium), id jka07-01447. 1 त $\mathrm{Ka}$ : Hamina, Hietakylä, 2.VI.1972, leg. L. Tiensuu, id http://id.luomus.fi/HT.785. 4 ○ $A b$ : Korppoo, Utö (6643:3184), 1.I.-26.VI.2006, leg. J. Joki- nen. 1 đิ same locality, 26.VI.-2.VII.2006, leg. J. Jokinen.

\section{Fannia pauli Pont, 1997}

New to Finland within borders after World War II. Hennig (1955): "Finland (Sortavala: Tiensuu 1935)". Sortavala is in Russian Karelia.

Material examined. FINLAND 1 त $A b$ : Korppoo, Utö (664:318), 15.-17.VII.1999, leg. Blomster \& Elo. 1 ऽ $A b$ : Korppoo, Utö (6643: 3184), 1.I.-26.VI.2006, leg. J. Jokinen. Same locality and leg: 2 ๙ 26.VI.-2.VII.2006. 6 ๙ 2.8.VII.2006. 2 ○ 8.-22.VII.2006.

\section{Fannia slovaca Gregor \& Rozkošný, 2005}

New to North Europe. This recently described species was previously confused with $F$. umbratica (Gregor \& Rozkošný 2005); the male genitalia figures in Rozkošný et al. (1997) belong to this species. Pre-war collecting localities of Rolf Krogerus in Kuusamo are spread on both sides of the current border between Finland and Russia. The exact collecting locality, and thus, the country of the second specimen remains unknown.

Material examined. FINLAND $1 \hat{\jmath} A b$ : Karjaa, Nordlingsberget (66653:33240), 17.V. 2006, leg. J. Kahanpää, id jka06-00217, reared from a pupa found within soft heart rot of a spruce (Picea abies) stump on a clearcut. Illustrated in Fig. 2. FINLAND or RUSSIA: $1 \lesssim K s$ : Kuusamo, 'Ti', 28.VI.1935, leg. R. Krogerus, id http:// id.luomus.fi/HT.797.

\section{Fannia stigi Rognes, 1982}

New to Finland. A Palaearctic species, previously known from Sweden, Norway (Rognes 1982) and China (Wang et al. 2007).

Description of the female. See Fig. 3.

Head. Frons broad, distance between eye margins about as wide as one third of head width. Eyes bare. Parafacials bare and densely grey dusted. Fronto-orbital plates entirely grey dusted but much less than grey parafacials. Fronto-orbital plates as broad as frontal vitta at narrowest part. Upper postocular setulae uniserial. Palpi distinctly spathulate and about as broad as three fourth of antennal flagellomere. Theca of proboscis shining and moderately long, not transversely broadened. 


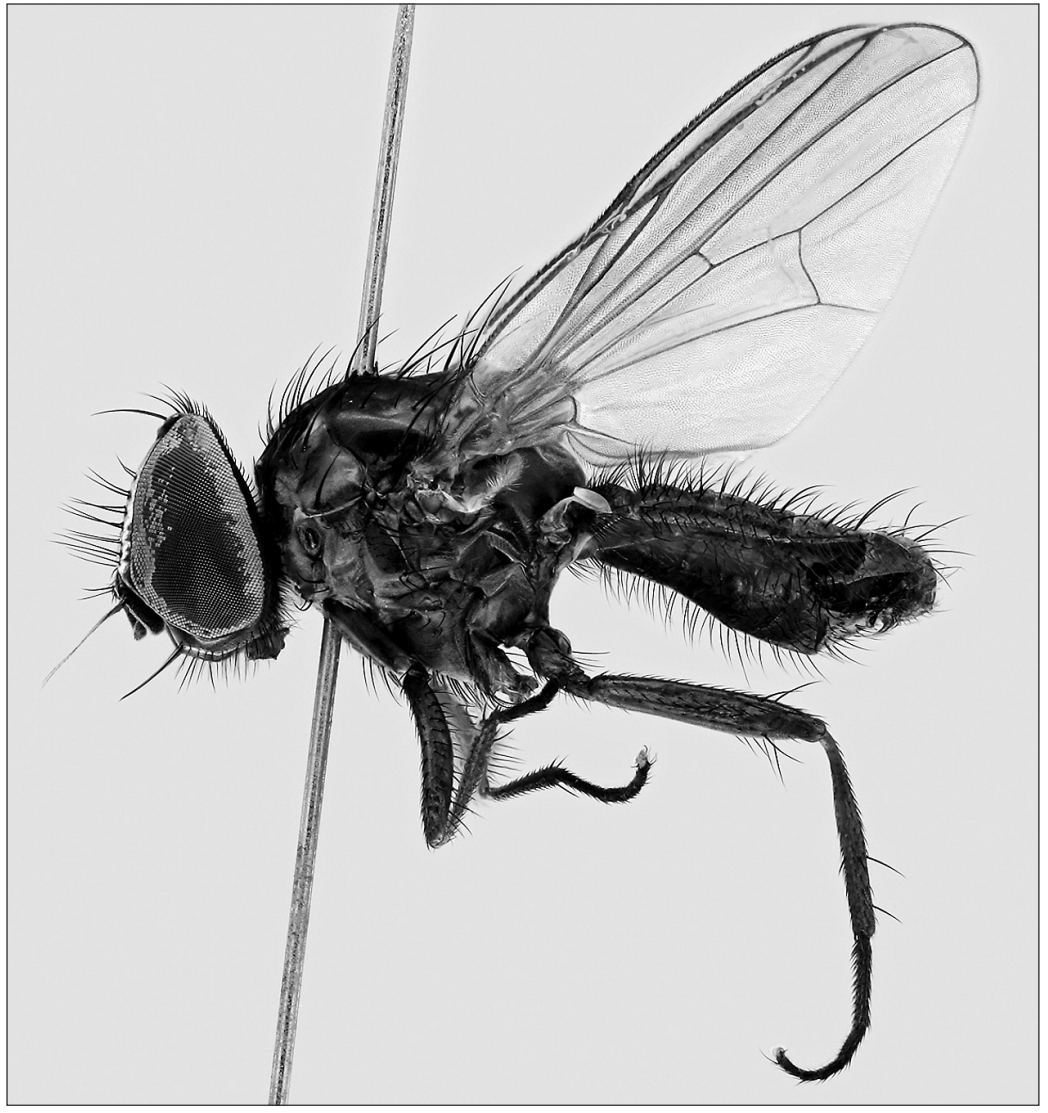

Fig. 2. Fannia slovaca Gregor \& Rozkošný, 2005, male. Middle legs missing.
Thorax. Shining black but distinctly grey dusted. Mesonotum without darker longitudinal stripes. Acrostichal setulae triserial. Two prealar setae, length of anterior one about one fourth of posterior notopleural setae. Calypters white and with white fringe. Lower calypter almost as broad as upper calypter.

Legs. Dark, base of femora translucent brownish. Fore femora with complete rows of short posterodorsal, posterior and postoventral setae. Fore tibia only with preapical setae. Mid femora apically with 3 posterior setae and with complete row of short anterior setae. Mid tibia slightly thickened in apical half. Mid tibia with 1 anterodorsal and 1 posterodorsal setae and without anteroventral setae. Hind femora apically with 2 anterodorsal and 2 anteroventral setae and with complete row of short anterior setae. Hind tibia with 1 anterodorsal and 1 anteroventral setae. Inner posterior margin of hind coxa bare.

Abdomen. Shining black but slightly grey dusted.
The female of Fannia stigi runs to the couple 63 in the key in "The European Fanniidae (Diptera).” (Rozkošný et al. 1997) and it does not key out.

Material examined. FINLAND $1 \curvearrowright \mathrm{Li}$ : Utsjoki, Outakoski, 13.VI.1948, leg. E. Thuneberg (id http://id.luomus.fi/HT.796). 1 ๙ Ka: Hamina, Potsila, 28.VI.1971, leg. L. Tiensuu (id HT.801). 1 ô 1 † Le: Enontekiö, Lossujärvi (76908: 32632), 9.-15.VII.2009, leg. R. Jussila, malaise trap.

\section{Fannia subatripes d'Assis-Fonseca 1967}

Listed from Finland by Pont (2012).

Material examined. FINLAND 1 ๙ Lkoc: Kolari, Ylläs (750016:337977), 1.-7.VII.2012, leg. A. Haarto, meat bait trap. $1 \hat{\delta}$ as previous but caught with a malaise trap. Both traps were near a subarctic forest spring near the treeline.

Fannia subpubescens Collin, 1958

Previously mentioned by Hedström (1968) and 
Fig. 3. Fannia stigi

Rognes, 1982, female.

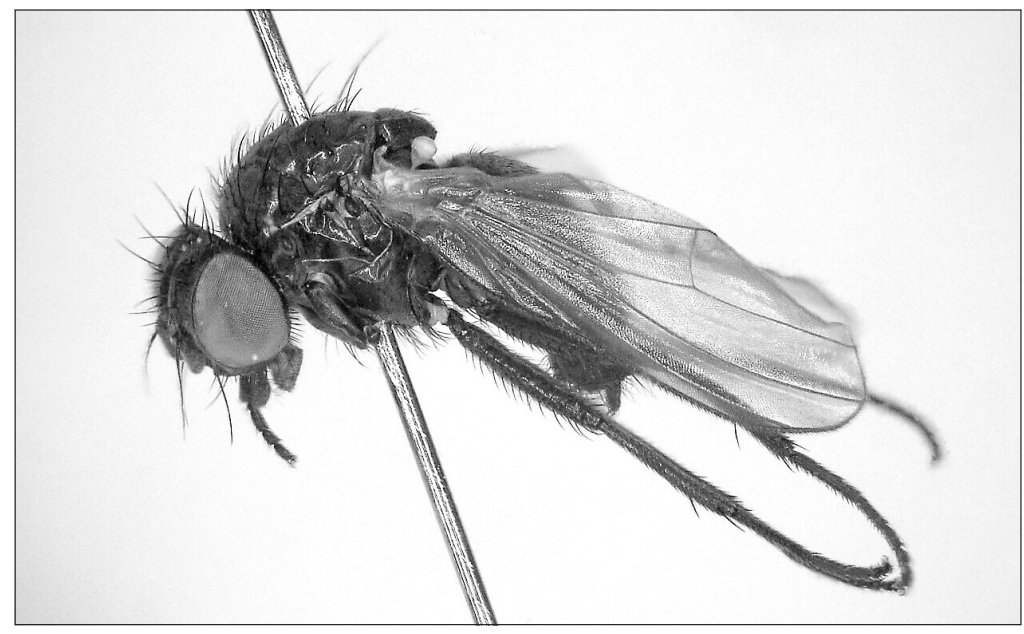

by Tiensuu (1940) as F. pubescens [auct, nec. Stein].

Material examined. FINLAND 10 กิ N: Helsinki, Koskela 8.VII.1940, leg. L. Tiensuu. 1 ô as previous but 28.VI.1940. $1 \hat{\sigma}$ as previous but 30.VI.1940. 1 \& $A b$ : Turku, Satava (67047: 32310), 7.VI.2001, leg. Hertta Winqvist, garden. 1 ô $N$ : Helsinki, Viikki Arboretum (668029: 338967), 5.VI.2006, leg. Jari Flinck, id JF064316. 1 \& $N$ : Loviisa, Harmaakallio (670413: 345667), 25.VI.2006, leg. Jari Flinck, id JF060653. 1 + $N$ : Vantaa, Vehkalanmäki (66881: 33799), 8.V.2008, leg. J. Kahanpää.

\section{Fannia umbratica Collin, 1939}

New to Finland.

Material examined. FINLAND 1 ๙ Li: Utsjoki, Outakoski, 13.VI.1948, leg. E. Thuneberg, id http://id.luomus.fi/HT.798. 1 त Sb: Kuopio, Kuvemäki (6960:3528), 23.-25.V.2003, leg. Eino Räsänen. 1 ô Lkoc: Muonio, Olos (75415: 33676), 5.VII.2012, leg. A. Haarto, det. A. C. Pont, id AHa12-002039. RUSSIA 1 ๙ Murmansk district, Petsamo, Yläluostari, north of the tourist hotel, 21.VI.1928, leg. W. Hellén, riverside meadows and bogs, id http://id. luomus. fi/HT.799.

\section{Fannia umbrosa (Stein, 1895)}

New to Finland within borders after World War II. Hennig (1955): "Sünfinnland [sic] (Tiensuu 1940)". The localities listed by Tiensuu (1940) are Terijoki and Sortavala Rytty (both now in
Russia). The Russian male from Sortavala, 17.VII.1934, leg. L. Tiensuu, "F. umbrosa Stein", id http://id.luomus.fi/HT.794) turned out to be $F$. ringdahlana Collin, 1939.

Material examined. FINLAND $1 \lesssim A b$ : Turku, Satava (67043:32307), 5.VII.2003, leg. K. Winqvist, black alder forest. $1 \bigcirc A b$ : Mynämäki, Perkko (6733:3222), 25.VI.2010, leg. A. Haarto, id AHa10-001094. 1 § Ta: Hämeenlinna (6762: 3359), 25.VI.2007, leg. T. Järveläinen. RUSSIA 2 ๙ Leningrad Oblast, Terijoki, 11.VI.1939 (id http://id.luomus.fi/HT.801) and 13.VI.1939 (id HT.800), leg. L. Tiensuu.

\section{Fannia verrallii (Stein, 1895)}

New to Finland.

Material examined. FINL AND 1 \& $A b$ : Sammatti, 16.VI.1936, leg. R. Krogerus, id http://id.luomus.fi/HT.778. 1 † $A b$ : Pukkila, Venunmetsä (67284:34159) 11.VI.2011, leg. J. Kahanpää, old growth forest, id Jka11-00130, iBOL DNA fingerprint voucher specimen. 1 \% Sa: Mikkeli, Kärmessuo (68575:35126) 30.VI.2010, leg. J. Kahanpää, bog+old boreal forest, id jka10-02786. 1 + Oa: Kristiinankaupunki, Nedermossen (68984: 32108) 27.VII.2012, leg. K. Winqvist, peat bog. 1 \& Ok: Suomussalmi, Hossa (726392:361918) 27.VI.1.VII.2011, leg. Reijo Jussila, malaise trap, id AHa11-004538. 1 q Ks: Kuusamo, Oravisuo (73513:36162) 11.VII.2010, leg. J. Kahanpää, peat bog, id jka10-00989. 1 \& $K$ : Kuusamo, Rinteenlammit (73639:36114) 13.VII.2010, leg. J. Kahanpää, a fen with springs, id jka10-01494. 


\section{Fannia vesparia (Meade, 1891)}

New to Finland within borders after World War II. Hennig (1955): "Südfinnland (Salmi nach Tiensuu 1935; var. fumigera aus Sortavala)". No specimens were found at MZH, where Tiensuu's collections are deposited. Both Salmi and Sortavala are in Russia.

Material examined. FINLAND 1 o $S b$ : Kuopio, Puijo (6978:3533), 31.VII.2012, leg. A. Haarto, id AHa12-002416.

\section{Fannia vespertilionis Ringdahl, 1934}

New to Finland.

Material examined. FINLAND $1 \lesssim N$ : Raasepori, Tammisaari, Dragsvik (6657:3303), 8.14.VII.2011, leg. H. Jalava \& H. Tanner, coastal deciduous forest.

\section{Piezura graminicola (Zetterstedt, 1846)}

New to Finland.

Material examined. 1 o $\mathrm{Al}$ : Lemland, Granboda, 16-21.VII.2004, leg. Gunilla Ståhls, malaise trap. 1 ○ $A b$ : Korppoo, Utö (6643:3184), 22.VII.-4.VIII.2006, leg. J. Jokinen, id AHa09000506. 1 \& $N$ : Loviisa, Harmaakallio (670413: 345667), 12.VII.2006, leg. Jari Flinck, malaise, id JF06-1842. 10 exx $N$ : Helsinki, Herttoniemi Fastholma (66787:33905), 1.VIII-3.IX.2006, leg. J. Flinck, malaise.

\section{Piezura pardalina (Rondani, 1866)}

Locally rather common in coastal alder forests on the south coast.

Material examined. FINLAND 1 o $A b$ : Kemiö, Sjölax kartano (66774:32689), 3.VIII. 2009, leg. A. Haarto, id AHa09-001401. 1 ○ $A b$ : Kemiö, Söglö Norrgård (66729:32478), 5.VIII. 2009, leg. J. Kahanpää, id jka09-05660. 1 † Al: Finström, Bergö Husö (6706:3103), 8.-9.IX. 2012, leg. Anssi Teräs, id AHa12-002212. 1 q N: Loviisa, Harmaakallion multavarasto (670132: 845656), 2.-3.VII.2010, leg. Jari Flinck, id JF105929. 355 exx from $N$ : Loviisa, Hagalundin jalopuulehto (67061:34578), 15.VII.-31.VII. 2010, leg. J. Flinck, beer bait traps. 1 \& : Helsinki, Herttoniemi Fastholma (667876: 339050), 11.-12.IX.2010, leg. J. Flinck, beer trap, id JF1010004.

\section{Deletions from the Finnish checklist}

\section{Fannia barbata (Stein, 1892)}

Hennig (1955) "Finnland (Ostkarelien: Kolatselkä nach Tiensuu, 1946)", Pont (1986, 2012) and Rozkošný et al. (1997) record this species from Finland. The source for all these is probably Tiensuu (1946a): "2 $\widehat{\sigma}$ in Ostkarelien, AK: Kolatselkä, 18.V.1943". Kolatselkä belongs to the Russian Republic of Karelia. No specimens were found in Finnish collections, but there is a male F. spathiophora Malloch, 1918 collected from Kolatselkä on 18.VI.1943 (id http://id. luomus.fi/HT.782) which may be one of the specimens referred to by Tiensuu. It is possible that the Palaearctic Catalogue record from North European Russia (NET) is also based on Tiensuu's missing specimens. It should probably also be considered doubtful until the specimens are found and identifications confirmed.

\section{Fannia lineata (Stein, 1892)}

The only published record of this species in Finland is by Tiensuu (1938): " $1 \curvearrowright$ in V: Naantali, 23.VI. 1935, on flowers of Anthriscus silvester (L.) Hoffm.". The only fanniid in MZH collections matching the published data is a male of male Fannia similis (Stein, 1895) labeled "Naantali/L. Tiensuu/Anthriscus silv./23.VI. 1935" (id http://id.luomus.fi/HT.780).

\section{Fannia nigra Malloch, 1910}

Hennig (1955) "aus S.O.-Finnland (Tiensuu 1940)", Pont (1986, 2012) and Rozkošný et al. (1997) note the species from Finland. Tiensuu (1940) mentions only specimens from Terijoki = Zelenogorsk (now in Leningrad Oblast, Russia) and Sortavala (Republic of Karelia, Russia). The notebooks of Lauri Tiensuu mention a Finnish specimen ( $K a$ : Hamina, Kannusjärvi, 14.VI. 1971, leg. LT), but no such specimen has been found in collections. We are not aware of any confirmed records from within the current borders of Finland.

Material examined. RUSSIA 1 ○े Leningrad Oblast, Terijoki, 16.VII.1938, leg. L. Tiensuu, id http://id.luomus.fi/HT.770. 


\section{Other notes}

\section{Fannia latifrontalis (Stein, 1892)}

Tiensuu (1946b) originally added this species (as Fanniosoma latifrons Ringdahl, 1932) to the Finnish fauna on the basis of a single male specimen collected by sifting a Lasius fuliginosus ant nest (N: Vantaa, Tammisto, 21.V.1946., leg. E. Kangas, det. L. Tiensuu). He described the male as having "... Behaarung der Augen und die Beborstung der Wangen" [hairy eyes and setose parafacialia]. Unfortunately Tiensuu never published the description he intended to write, and we could not find this specimen in MZH. The record could not be confirmed without specimens. Nonetheless, we accept it for now.

\section{Fannia rabdionata Karl, 1940}

The type locality of this species was given as "Finnland (Magala am Luirojoki)" by Karl (1940). We did not find any material in MZH. It has recently been redescribed from Chinese material (Wang et al. 2007). While 'Magala' could not be found on any maps we consulted, the type locality is definitely within the current borders of Finland.

Acknowledgements. We would like to thank Dr. Adrian C. Pont of the Oxford University Museum of Natural History for valuable advice on identifying female Fannia, Pekka Malinen (MZH) for taking the first two photographs, and all the Diptera enthusiasts who allowed us to examine their collections.

\section{References}

Gregor, F. \& Rozkošný, R. 2005: A new species of Fannia (Diptera, Fanniidae) from Central Europe. - Biologia (Bratislava) 60(5): 519-522.

Haarto, A. 2009: 3.2 Kaksisiipiset (Diptera). — In: Hyvärinen, E. \& Sulkava, P. (eds.), Hyönteiskartoitukset Annjaloanjilla ja Toskaljärven ympäristössä Käsivarren erämaa-alueella 2007 ja 2008. Metsähallituksen luonnonsuojelujulkaisuja, Sarja A 185: 21-25. Metsähallitus, Helsinki. 78 pp.

Hackman, W. 1980: A check list of the Finnish Diptera II. Cyclorrhapha. - Notulae entomologicae 60: 117162.

Hedström, L. 1968: Muscidae s. str. (Diptera) from SouthWest Häme. - Lounais-Hämeen Luonto 27: 1-13.
Heikinheimo, O. \& Raatikainen, M. 1971: The recording of localities of biological finds in Finland. - Annales Entomologici Fennici 37(1): 9-12.

Hennig, W. 1955: 63b. Muscidae. - In: Lindner, E. (ed.), Die Fliegen der Palaearktischen Region, Band VII(2): 1-96. E. Schweizerbart'sche Verlagsbuchhandlung, Stuttgart. $1110 \mathrm{pp}$.

Karl, O. 1940: Neue paläarktische Musciden (Anthomyiiden) (Diptera). — Stettiner Entomologische Zeitung 101: 41-47.

Nishida, K. 1974: On Eight Species of the Genus Fannia (Diptera, Muscidae) from Japan, with the Description of New Species. - Japanese journal of entomology 42(2): 184-191.

Nishida, K. 1994: The Fanniidae from Nepal (Diptera). Japanese Journal of Sanitary Zoology Supplement 45: 81-97.

Pont, A. C. 1970: A new species of Fannia Robineau-Desvoidy from the Alps (Ins., Diptera, Muscidae). - Berichte des Naturwissenschaftlich-Medizinischen Vereins in Innsbruck 58: 343-346.

Pont, A. C. 1986: Family Fanniidae. — In: Soós, Á. \& Papp, L. (eds.), Catalogue of Palaearctic Diptera. Scathophagidae-Hypodermatidae. Volume $11: 41-$ 58. Akademiai Kiado, Budapest \& Elsevier, Amsterdam. 346 pp.

Pont, A. C. 2012: Fauna Europaea: Fanniidae. — In: Pape, T. \& Beuk, P. (eds.) Fauna Europaea version 2.4 [www document]. URL http://www.faunaeur.org/. (Site visited on 17 December, 2012).

Rognes, K. 1982: Fannia stigi n. sp. from Scandinavia (Diptera: Fanniidae). — Entomologica Scandinavica 13(3), 325-330.

Rozkošný, R., Gregor, F. \& Pont, A. C. (1997): The European Fanniidae (Diptera). - Acta Scientiarum Naturalium Academiae Scientiarum Bohemicae, Brno (New Series) 31: 1-80.

Tiensuu, L. 1938: Beiträge zur Kenntnis der Musciden (Dipt.) Finnlands. - Annales Entomologici Fennici 4(1): 21-33.

Tiensuu, L. 1940: Für die Fauna Finnlands neue Musciden (Dipt.). - Annales Entomologici Fennici 6(4): 154 157.

Tiensuu, L. 1941: Brachycera (Muscidae, Tachinidae). Enumeratio Insectorum Fenniae. V I Diptera 32-43. Helsingin hyönteisvaihtoyhdistys r.y., Helsinki.

Tiensuu, L. 1946a: Beiträge zur Muscidenfauna Nordeuropas (Dipt.). - Annales Entomologici Fennici 12(2): 63-68.

Tiensuu, L. 1946b: Zur Fliegeneinwohnerschaft eines Ameisennestes. - Annales Entomologici Fennici 12(2): 73-74.

Wang, M., Liu, L., Wang, R. \& Xue, W. 2007: Review of the F. scalaris species-group of the genus Fannia Robineau-Desvoidy, 1830 (Diptera: Fanniidae) from China. - The Pan-Pacific Entomologist 83(4): 265-275. 